\title{
Obstacles and Countermeasures for the Development of Agricultural Electronic Commerce Under the Construction of New Countryside
}

\author{
Wanshan Han
}

\author{
Arts and Social Sciences, The University of Sydney \\ Sydney, Australia \\ whan3771@uni.sydney.edu.au
}

\begin{abstract}
The development of agricultural E-commerce is an essential task in the construction of a new countryside. It is not only conducive to improving the degree of agricultural industrialization and reducing the transaction costs of agricultural products, but also increasing farmers' income and narrowing the gap between urban and rural areas. By analyzing the obstacles to the development of agricultural e-commerce in China, it is recommended that the government continue to increase investment and at the same time use the guiding role of relevant policies to attract powerful enterprises to participate in the construction of agricultural e-commerce. For example, form a diversified agricultural e-commerce construction system; encourage and develop mobile wireless networks to promote the development of agricultural mobile e-commerce; provide diversified information services needed by farmers; give full play to the role of college students returning to their hometowns, and help local farmers to establish and maintain website, carry out farmer training, improve the quality of farmers, and serve the construction of new countryside.
\end{abstract}

Keywords: New countryside construction, Agricultural E-commerce, Countermeasure

\section{INTRODUCTION}

The construction of new socialist countryside is an inevitable requirement to meet the economic and social development of China which country has over 900 million farmers. The problems of agriculture, rural areas and farmers are related to the overall development of the Chinese national economy. Agriculture is at the foundation of the national economy and the development of the rural economy is lagging behind the development of the industrial economy. E-commerce, as an advanced business model, allows farmers to obtain more information services and to carry out various economic activities for commodity trading in a highly efficient and low-cost manner, which is conducive to improving the industrialization of agriculture, reducing the transaction costs of agricultural products and expanding the market scope of agricultural products, thereby raising farmers' income, narrowing the gap between urban and rural areas, improving agricultural productivity and promoting the rapid development of China's agricultural E-commerce.

\section{THE DEVELOPMENT PROCESS OF AGRICULTURAL E-COMMERCE IN CHINA}

Agricultural E-commerce refers to the electronic transaction activities generated in the process of agricultural production and operation[1]. The use of the Internet, computers and other modern information technology to achieve the sale of agricultural products and procurement of agricultural production materials, as well as the development and promotion of agricultural production and management technology, agricultural production and management information services, labour export services, agricultural technical support, knowledge training, labour information and other agriculture-related applications.

In the late 1980s, computer and network technology began to be applied in the agricultural field. In the mid1990s, the Chinese government put forward the "Golden Agriculture" project to promote the agricultural informatization. The "Golden Agricultural Project" implementation has laid a good foundation for 
developing agricultural E-commerce in China[2]. In the 21 st century, with the widespread application of Internet technology in agriculture, information technology in China's agricultural sector has entered a stage of rapid development. Since 2003, the Ministry of Agriculture has established a system for collecting and publishing agricultural information, set up an agricultural information network and implemented a system for the monthly publication of agricultural market monitoring and early warning information, which has led to a gradual expansion of the coverage of information publication and the gradual improvement of the agricultural information network[3]. The information system has taken initial shape, enabling the convenient and quick realisation of rural e-government, township government internet access and information release and inquiry.

\section{BARRIERS TO THE DEVELOPMENT OF E-COMMERCE IN CHINA'S AGRICULTURE}

Although China's agricultural E-commerce has made significant development with the support of national policies and the support of local governments, there is still a big gap compared with the development of agricultural E-commerce with other industries. The following obstacles to the development of agricultural E-commerce in China mainly exist:

\subsection{Information asymmetry between agricultural production and market demand persists}

China's agriculture is a small-scale family-based production unit, and individual farmers cannot adapt to the rapid changes in the agricultural market, and there is a contradiction between "small farmers and big market". The information asymmetry between agricultural production and market demand makes the marketing of agricultural products one of the critical factors limiting the development of agriculture in China, especially with the increase in agricultural productivity and the marketisation of agricultural products, the market for agricultural products is gradually moving towards a buyer's market where supply exceeds demand[4]. In contrast, the primary channels for farmers to obtain information are still traditional methods including television, exchanges between farmers, technical promotion by scientific and technological personnel, radio and newspapers. Most farmers still determine the type and scale of production of agricultural products based on previous market prices and experience, which often differs to some extent from market demand. If there are large changes in market demand, it not only affects the sale of agricultural products, but even causes serious backlogs and waste, affecting the overall stability of agricultural production and overall stability of agricultural production and farmers' enthusiasm.

According to the 2008 statistics of CISDI.com, there are more than 17,000 websites related to agriculture in China, but most of them are similar form to content, lacking in features, not professional and practical enough, and can provide less information to guide farmers' production, which cannot make farmers understand market information timely and organize production reasonably according to market demand[5].

\subsection{Rural network infrastructure development is taking shape but still needs to be improved}

Chinese rural areas are widely distributed, and the existing network communication infrastructure in rural areas is weak, and it is difficult to adapt to the requirements of the rapid development of agricultural Ecommerce. Although the government attaches great importance to agricultural E-commerce, it has invested a lot of financial resources in the construction of rural informationization[6]. Compared with the requirements of agricultural E-commerce, there is still a particular gap in the construction of rural information infrastructure, especially the limited investment in information construction at the county and township levels. The characteristics of high agricultural investment and long cycle determine its lack of investment attractiveness and attention, and lack of complete and efficient infrastructure and communication facilities hinder the rapid development of agricultural E-commerce.

The China Internet Information Center found that the level of Internet development is positively correlated with the level of regional economic development, that is, the more developed the regional economy, the more developed the Internet will be. Some rural areas do not have the basic conditions for Internet use, especially the rural areas in the central and western regions. Differences in natural conditions have caused unbalanced development between North and South. According to a CNNIC survey in June 2007, the Internet penetration rate among rural residents in China is $5.1 \%$. The geographical distribution of rural netizens is quite uneven, mainly concentrated in Beijing, Shanghai, Zhejiang, Guangdong and other places. The central and western regions have the small proportion of netizens in less developed areas. For most farmers, computers are still a piece of luxurious electronic equipment. At the same time, broadband access costs are also a massive burden for farmers to use the Internet. The proportion of not using the network due to lack of corresponding hardware is higher than that of urban, which restricts farmers from accessing the Internet. 


\subsection{The lack of farmers' informatization knowledge does not match the technical requirements of E-commerce}

E-commerce, as a new type of transaction mode, involves the computer and network technology, and requires high levels of knowledge and operational skills for operators, but there is a shortage of people who understand computer technology and network knowledge in rural areas. The limitation of the rural social economy and cultural environment makes professionals who understand to be reluctant to go to the countryside, and the rural areas cannot train talents by themselves. Only the college students who return to their hometowns can operate the network proficiently. The severe shortage of E-commerce talents has affected the rapid and technological development of rural Ecommerce areas.

According to statistics by the China Internet Information Center at the end of December 2009, the number of rural netizens reached 106.81 million, accounting for $27.8 \%$ of all netizens. The year-on-year increase is $263 \%$, which is lower than the growth rate in 2008 and the overall increase in netizens in 2009. Among rural non-netizens, $38.8 \%$ do not use the Internet because they do not understand computers and the Internet, and $84.7 \%$ of rural residents often choose to obtain information from television[7]. Thus, netizens, farmers do not know how to use the Internet to obtain and release information, lack of E-commerce related knowledge and comprehensive ability to implement, the use of information resources is not efficient, and information products are challenging to bring economic benefits to farmers, which restricts the development of agricultural E-commerce.

\section{REMOVING BARRIERS TO AGRICULTURAL E-COMMERCE DEVELOPMENT}

\subsection{Government support and multi-channel development simultaneously}

The government needs to continue to invest heavily to strengthen the infrastructure construction of agricultural informatization. Weak infrastructure restricts the development of agricultural E-commerce. Therefore, building new countryside and developing agricultural E-commerce requires corresponding measures to be taken in accordance with the natural and economic conditions, and financial investment is tilted toward rural infrastructure and promoted in various ways. For example, information services realize broadband access from the village to village, solve the problem of the "last mile" of information, realize interconnection and intercommunication of networks at all levels from top to bottom, improve network quality and coverage in rural areas, and continue to increase access to agricultural information resources integration, development and utilization. The U.S. Department of Agriculture and the Department of Commerce and the U.S. Small Business Administration set up a small business E-commerce working group to promote the development of E-commerce by enterprises including small agricultural enterprises, broaden the sales channels of agricultural products, reduced transaction links and transaction costs, and brought benefits to the agricultural economy[8]. The Ministry of Agriculture, Forestry and Fisheries of Japan formulated a strategy for vigorously developing agricultural E-commerce and rural informatization in December 2000 to promote fundamental changes in the circulation of agricultural products[9]. Its agricultural E-commerce has a variety of forms to meet the needs of different farmers, from large-scale integrated online trading markets, agricultural electronic exchanges to agricultural online stores, which can be traded through purchase, sale, auction or directly signed with producers. It not only guarantees the freshness of agricultural products, but also reduces the price.

\subsection{Provide diversified information services needed by farmers}

Government departments organize rural public information resources to ensure the fairness, timeliness and authenticity of information use. Strengthen the overall planning of agricultural information resources, promote its integration and sharing, promote the standardization and standardization of rural information, improve the information collection and release system, pay attention to the development and utilization of characteristic rural information resources, make full use of existing resources, enrich agricultural information resource databases, and strengthen information The management of agricultural information services breaks the information separation between regions and industries and solves the problem of "information islands". Through institutionalization, the situation of repeated collection of information, monopoly use and inefficient development will be changed, and public information services such as national policies and regulations, agricultural science and technology, market supply and demand, ecological environment, and agrometeorology will be provided for agricultural producers to realize the sharing of information resources. With regard to the provision of market information, Japan uses a unified agricultural technology information network to link pests and diseases with forecast systems, meteorological information systems, agricultural production management systems for universities, and agricultural production and sales information systems, and stipulates that local wholesale markets are obliged to be timely The daily sales and purchase quantities and prices of various agricultural products will be 
announced on the Internet. The Agricultural Information Service Center established by the agricultural departments of the Canadian federal and provincial governments provides information services such as agricultural laws and regulations, policies, disasters, business management, and trends in the supply and demand of agricultural products to farmers, rural residents, and agricultural product distributors free of charge. Toll-free telephones for information consultation can be provided on the website to answer questions asked by farmers, and information consultation services can also be provided through online e-mails[10].

The government uses policies to guide and support powerful enterprises to engage in agricultural Ecommerce, starting from providing free information that farmers need, guiding farmers to understand the market, so that farmers can benefit from obtaining information, thereby attracting farmers to enter the market. On this basis, take farmers as the center, re-understand and design the agricultural industry chain, eliminate information asymmetry, reduce various risks faced by farmers, save transaction costs, and let farmers feel the income-increasing effect of agricultural E-commerce and encourage farmers to conduct information consultations with agricultural information departments and experts through telephone, computer networks and other means to keep abreast of market prices and supply and demand conditions of agricultural products in a timely manner, and give full play to the role of Ecommerce in agricultural production and operation and farmers' income increase.

\section{CONCLUSION}

In conclusion, one of the critical factors for the development of agricultural E-commerce is to have professional and technical personnel who have been systematically and professionally trained to serve farmers. The government should select and absorb agricultural E-commerce professionals through various forms, establish an agricultural E-commerce professional team with professional skills and analytical and application capabilities, and promote the construction and development of agricultural Ecommerce. Make full use of college students returning hometowns with computer network application knowledge to help grassroots farmers establish and maintain websites, provide information on agricultural science and technology needs, agricultural products supply and demand, and serve the local new rural construction. At the same time, strengthen the training of E-commerce talents, cultivate professionals in information collection, information processing, information release and information system development, and build the agricultural business website.
Set up as a platform that truly serves agriculture, rural areas and farmers.

The government needs to further increase investment in farmer information technology training, mobilize various education and training institutions in the society, and organize agricultural information technology training courses in the vast rural areas to cultivate and improve farmers' ability to understand and use information, and conduct electronic training on farmers in various forms. The Business training can improve the quality of farmers. For example, organize various agricultural colleges and universities to send knowledge and culture to the countryside, and conduct targeted and regular training on Internet knowledge and E-commerce common sense for farmers. It can also make full use of the advantages of the Internet to conduct distance education and training to solve the problem of poor informatization quality of farmers. The problem has made farmers realize that they are both the main participants and beneficiaries of agricultural Ecommerce. It can also mobilize farmers' enthusiasm for learning information technology through effective forms such as holding farmers' online contests. By improving their quality, they have the skills to use information, and are better at using information technology to improve agricultural production.

\section{REFERENCES}

[1] SP, Chen. The development of foreign agricultural e-commerce and its enlightenment to the country, Journal of Agricultural Library and Information Science,vol.9,pp.112-114,2018.

[2]YM, Fu. Informatization is the key to building a new countryside. China Science and Technology Information ,vol.10, pp.96-98,2009.

[3]HP, Peng.Research on the transaction cost of agricultural product e-commerce,Journal of Yangtze University (Natural Science Edition),vol.4, pp.115-117,2008.

[4]ZG, Zhang and HL, Sun.Transaction costs and the development of agricultural BtoC ecommerce,Economic Forum, vol.14,pp.112114,2005 .

[5]Hl,Wang and AL,Conception of rural e-commerce development. Economic aspect ,vol.2, pp.3840,2007 .

[6]D, Wang.Investigation and Analysis of Farmers Information Needs: Taking Ningxia as an Example. Journal of Agricultural Library and Information Science ,vol.7, pp.7-13,2009.

[7]Baourakis, M. Kourgiantakis, A. Migdalas.The impact of E-commerce on agro-food marketing: 
The case of agricultural cooperatives, firms and consumers in Crete, British Food Journal, vol.8, pp.580-590,2002.

[8]O.Folorunso,Sushil K.Sharma,H.O.DLonge,K.Lasaki. An Agent-based Model for Agriculture Ecommerce System, Information Technology Journal.2006,5(2):230-234.
[9]Mueller,R.A.E. E-commerce and Entrepreneurship in Agricultural Markets. American Journal of Agricultural Economics, vol.83, pp.243-1249,2001.

[10]Williams,J.E-commerce and the Lessons from Nineteenth Century Exchanges. American Journal of Agricultural Economics, vol.83, pp.1250$1257,2001$. 